\title{
A Response to Gradual Globalization: Regionalism
}

\author{
Irah Kučerová*
}

\section{Globalization of the World Economy}

The end of the $20^{\text {th }}$ century has brought a number of both qualitative and quantitative changes in the functioning of the world economy. A new phenomenon is the process of the economic globalization implementing itself fully which has become the impulse for other developmental changes.

The process of the economic globalization limiting the autonomy of national subjects completed the disintegration of the Westphalian system, when a state was not capable to control fully the activities of the economic subjects within its territory. But, the national states, especially in Europe, are responsible for the protection of public interests and for the supply of public goods. This dichotomy between the state power and the economic effectiveness leads to the current crisis of states, let us say crisis of the welfare states, when the strengthening competitive pressure of the liberalized world economy reduces social benefits, which the post-war generations were accustomed to. In Europe, this is especially reflected in a high degree of the institutional protection of the labour market and the pension systems that are entirely inconvenient nowadays.

The process of globalization has been enabled by the institutional and political changes of the world economy in the 80's. These changes have led to the transformation of economic relationships, intensified thanks to the technological discoveries and their practical application.

The gradual institutional standardization within the Uruguay Round of the GATT ${ }^{1}$ increased the mobility of capital, and, in the same round of the negotiations, the liberalization of the international trade led to the growth of the international exchange. The fall of the Iron Curtain unified the bipolar, divided world into one economic area.

Globalization has various definitions, yet, thanks to its multi-level character, it is necessary to render its most important aspects, at least. In any case, it is a process, in which the importance of the transnational and international companies within the economy of particular states is growing, and the shares of the direct foreign investments and import are going up. However, it is also a manifestation of an accelerated economic dependence of nations within the world system, which is mediated and amplified by the mass media and transport (Kottak: 1996). A logical consequence of this are changes in many aspects of the social existence of nations, states. Then, the economic globalization is a process, in which law, market and politics limit the autonomy of national subjects, because the development of economy and legislature also involves changes in politics.

The economic globalization has thus contributed to the disintegration of the Westphalian system of international relations. For nearly 350 years, this system regulated the position of the state in foreign relations, when the state was controlling fully the activities of all

\footnotetext{
* PhDr. Irah Kučerová, PhD.; Katedra mezinárodních vztahů, Fakulta sociálních věd Unoverzity Karlovy v Praze, kucerovi@fsv.cuni.cz.

1 Agreements about protection of investment and intellectual property - TRIMs, TRIPs.
} 
the subjects within its territory. The dependence on foreign capital and the activity of transnational companies reduce the influence of the state within its territory, let us say, they transform the role of the state, which is another characteristic feature of globalization. But, in spite of that, "the state retains its role least because of the fact, that, within its economic policy, it creates conditions for the functioning of the international economic subjects, including transnational companies, on its territory. Thus, globalization led to the change of the instruments which the political elites can choose from... "(Steinmetzová: 2005, p. 27)

As early as at the end of the 60 's, the world was compared to a global village (McLuhan: 1968), and, twenty years later, McLuhan offers his conception of globalization as a consequence of universal communication based on the increasing of the possibilities of the human brain by technology, which would enable to connect only seemingly isolated parts of the world. It is the technological changes that are major reasons for the social transformation. (McLuhan: 1989). Aron explains globalization as a process of the transformation of social relations, leading to the unification of the world as one organism, as one territory. (Aron:1968). Although the notion of globalization already appeared in the Oxford dictionary in 1964 and though various investigators used the term during the 60 's, trying to give it a content, the economic globalization did not appear until the turning of the 80's and 90's. The basic difference between the economic internationalization which has been spreading since the second half of the $19^{\text {th }}$ century, and the economic globalization, is the feedback between particular economic subjects. These interactions are actually evident at all levels of the world economy.

\section{Some Consequences of the Economic Globalization}

Some definitions of the economic globalization also account of regionalism, a developing phenomenon, transforming itself gradually from its geographical significance into institutional: so called new regionalism. This regionalism is characterized by the development of entirely new ways of the international labour division and by the interconnecting of economic subjects both within and beyond the particular geographic region. As a consequence, the economic globalization is reflected in the harmonization of the economic cycles, in the convergence of the rate of interest and the security rates in the stock exchange, all this having been enabled by the revolution of information technologies. (Brittan: 1996). However, the process of the economic globalization can be explained more concisely, that is, as a process of a relative contraction of time and space (Suša: 2004), let us say, that, when comparing time and space, time takes precedence over space, whose importance decreases. (Oi: 2005). All this favours the renaissance of regional cooperation and a regionalism based on attributes that are entirely different from the previous development of the geographical regionalism.

Globalization is another stage of the deepening specialization which profits from monopolistic mastering of particular technologies, and, thanks to that, also the implementation of diminishing returns, naturally, when using the comparable advantages of available resources: of raw materials, technological, qualifying or institutional (the functioning of the public administration, tax conditions, the flexibility of the labour market).

Regarding the fact, that ,globalization supports the spatial division of the places of production and the places of consumption, and the disintegration of the production complexity into partial processes and parts" ( Fárek: 2005, p. 7), the ways of the international labour division change, and, above all, there are changes in the traditional production: changes of the cooperation and distribution structures. But, it is necessary to 
realize, that, in spite of the fundamental qualitative changes in the globalization process, there is no principal divergence from the actual development - on the contrary.

The economic globalization is the climax of the preceding process of the internationalization of economies, i.e. the penetration of foreign capital into national economies, and, at the same time, the expansion of the domestic capital abroad, with only a partial repatriation of profits. It is the culmination of the gradual opening of economies, when there is an increasing dependence of all the participating states on the international trade, the international capital flows, the migration of labour forces, and, especially, on the exchange of scientific-technical information.

The intensification of the international labour division is caused not only by the utilization of all available resources, but, above all, by the increase of the effectiveness of the economic process itself - as for the production, distribution, and business. The pressure on the effectiveness supports the overall competitive environment and, in consequence, the companies aim to have their expenses as low as possible. So far, there has never been such an extensive outsourcing in history. It means the transferring of production to another place where the expenses are advantageous. The institutional standardization has significantly reduced the risk of enterprising also in those parts of the world which had been refusing to guarantee security for foreign investment. The natural effort of every company, i.e. to maximize its profits when minimizing its expenses, leads to outsourcing also in the fields that had a traditional background in their countries of origin ${ }^{2}$.

\section{Reactions to Outsourcing}

For instance, in 2000, the European Union tried to react to the challenges of the world economic globalization by elaborating the Lisbon Strategy, but the encounter of the European vision with the reality of the economic policies at national levels showed that the Strategy had failed. Neither the New Lisbon Strategy, a revised approach of sympathetic Europe, does not seem to be very successful in the world labour division.

On one hand, the states try to defend themselves against outsourcing, but on the other hand, they support it deliberately. But, it is a question, what outsourcing actually concerns and which economies.

In a functioning market environment, the best protection against the capital outflow and the transferring of production to other countries is the adjustment of the tax and administrative regulations, removing of the deficiencies in the functioning of the public administration and in the preparations of various projects. This is also the reason, why, in the course of the 90's, the states adjusted the tax systems in favour of the direct taxes, not only by a partial reduction of the overall tax burden, but, above all, by transferring the main tax burden to the sphere of the indirect taxes. The choice of these taxes is much easier, cheaper, and therefore more effective. Apart from that, the consumer can hardly defend himself and the possibility to optimize his tax burden is much more limited and complicated. But, this way, the economic policy aiming at the support of the enterprise competitiveness, especially in a paternalistic Europe, comes into conflict with the principles of the welfare state. The high public consumption, the extensive public sector must be financed from the public funds, i.e. from the tax revenues mainly. These revenues, due to the possibility of the tax optimization of the companies, show a declining tendency.

2 A good example can be the originally European textile industry, as well as the Czech textile industry. During the 90 's, some of its private production companies moved to Slovakia, and later to Ukraine, and now they have also settled in China or Vietnam. 
The companies are having more and more possibilities to make decisions about their economic activities, the allocation of their production factors and the localization of their administrative seat. Due to the possibility of the tax optimization, there are higher capital flows, and outsourcing is a direct consequence of this optimization. The problem is related to the high rate of social security which is typical for the European social models. High payments for the obligatory social assurance leads to higher expenses of the companies, therefore, in the conditions of the capital liberalization, the companies transfer their production to an environment where the expenses are lower. But, the consequences are the reduction of production in regions that are more tax-demanding, the growing of unemployment, and therefore the growing demands for the payment of various social benefits. From this point of view, Europe, as a region, is especially in danger; there the abyss between the social standards guaranteed by the state, and the possibilities of the state to finance these standards, is deepening more and more. Therefore, globalization forces the European societies to reform their applied social models.

The provident governments of the most advanced and efficient economies do not try to prevent the transfer of old production technologies or fields of business with a lower rate of the added value to other countries or regions, because they see that the consequence of this process is more space for modern technologies. In such a case, the investment environment of the particular economy supports innovations, capital inflows and the inflows of qualified labour forces, and favours the development of the communication and transportation infrastructure.

But, the liberal approach of the U.S., or, if you like, of the United Kingdom, Netherlands, Finland, and Japan, which was adored for a long time, has got its disadvantages. It is true that production technologies and capital are modified very often, a higher number of new companies are established, and therefore new vacancies are created and more patents are registered. However, the drawbacks are usually the negative consequences on the labour market. For example, although the U.S. economy kept the unemployment at a natural level in the last decade of the $20^{\text {th }}$ century, it battled against the structural unemployment at the regional level (Stieglitz: 2001), because it would be false to suppose the immediate retraining of employers, for example, that the workers in the automobile industry become computer specialists ${ }^{3}$. It is to be pointed out, that we are talking here about the conditions of the extremely flexible American labour market which cannot be compared to the European or Japan rigidity.

The geopolitical system of the end of the $20^{\text {th }}$ century supports the development of geoeconomics, favouring the reduction of production and transaction costs, i.e. it supports outsourcing, and there is an increasing number of the subjects dependent on the global labour division. Paradoxically, this does not reinforce the stability of the international system, and the negatives of outsourcing deepen the regional disparities. Therefore, Samuelson assumes that it is not possible to let the process of globalization develop freely without intervening to it, because, "naturally, it is difficult to find and define the Aristotle's Golden Mean between the growth of wealth and equilibrated life stability." (Samuelson: 2005).

A possible defence against globalization and a potential investment outflow is, above all, the support of domestic companies, but not by means of the state aid, or subsidies, which is, except for some clearly defined exceptions, prohibited also by the WTO. The support of the domestic business sector should consist in a favourable tax environment, in tax relief for the investigation and development, in accelerated depreciation, in the rectification of the position of various sub-suppliers, or in the pro-export policy including an efficient aid of the state bodies when there is an expansion to foreign markets.

3 A popular remark of Bill Clinton's, made during his second election campaign, that the cancelled workplaces cannot be just replaced by new ones, but the only possible solution are the investments to increase qualifications for the vacant workplaces, and not only by retraining which may not be bound to the conditions of the new economics. 
Another sphere reacting to globalization is the labour market. In the post-industrial era of the knowledge based economy, a new phenomenon emerges: so called employability, as opposed to the aim of the economic policy - the employment. So called employability (Kirovová: 2006) is defined as a repeated need of the workforce to change jobs including the working conditions, and the organizational structure of the companies. There are changes in the work conditions, when the workload is increased by means of an increased delegating of competences, the teamwork, and the adoption of the just-in-time work method. Another characteristic feature of the employability is the decreasing demands on the limited professional specialization and the increasing demands on the application skills and so called soft skills that consist of the worker's activity, flexibility, the adaptability to changing conditions, and responsibility. The systemic support of employability is the answer to the changes of the socioeconomic factors and it is a way of how to face the consequences of globalization without stopping protecting the public interests.

This is connected with the support of competitiveness inside the companies, but only when there is an obliging company policy towards the employees, the support of the diversity of talents ( Hampden-Turner: 2005). A solution could be a combination of challenges and skills, when so called flow experience operates as a development accelerator: new challenges improve our skills, and, at the same time, our skills push forward our goals. It is a recommendation for the economic policy: when a certain degree of social securities is maintained, the business-oriented approach is supported (Czikzentmihaly, M.: 2005), which is actually the minimal necessary answer to the impact of globalization.

These are the only measures in accordance with fair competition which means, among others, the respect of the WTO principles (and therefore preventing possible business disputes). An effective means cannot be the protectionism of import, because this is actually the way to the hell of non-competitiveness.

The protectionism in the economic policy leads to the conservation of the old structure of the national economy. By reducing the competitive pressure on the domestic market, protectionism causes a temporary macroeconomic stabilization, which can lead to - and often it actually does - the stagnation of particular sectors or even of the whole economy. Nowadays, even some trade unions - the traditional defenders of the high institutional standards or import barriers - are aware of that fact. Therefore, the solution is the systemic aid with the ex ante support of the business activity, not as an ex post defence. The ad hoc defence against foreign competitive companies offering low prices is a bad approach; the industry has to adapt itself to the severe competition, or $\mathrm{die}^{4}$.

Another way of the defence against the negative consequences of globalization is the consumer support of the domestic products, and therefore, on one hand, there is an effort to create "national“ trademarks, and, on the other hand, there is a demand for the obligatory indicating of the country of origin on the products, provided that the loyal consumer would support the national, or, in case of the European Union, the European products. But the consumer behaviour is highly rational and if they can get comparable quality, and therefore the same utility value at a lower price, then they will rather maximize their consumer profit and, in most cases, they will not be interested in the country of origin of the product. Naturally, the exception will be the traditional national and regional products. The consumer optimization causes a decreasing competitiveness of some companies or regions, and this leads to the macroeconomic destabilization. In these conditions, the protection of the public interests will function in a different way. A possible reaction to globalization is regionalism.

4 Valeria Fedelio, an Italian trade union officer and a consultant of P. Mandelson, the European Business Commissioner, March 2006, in Lidové noviny, 1st April 2006. 


\section{Regionalism}

Regionalism, as a systemic approach to the protection of regional interests within the globalized economy, tries to affect outsourcing for the benefit of the particular region. „Regionalism shows the priorities of the economic subjects, and the governmental strategies in the economic, political, and even security and generally strategic spheres. At the same time, regionalism leads to the identification of the spheres of interests always within the particular geographic context, and this is so even nowadays, in the new regionalism era“'(Kučerová: 2006, p. 82), whose emergence is related to the process of the economic globalization.

Regionalism, as a part of the state economic policy, aims to use the comparable regional advantages and to strengthen its resistance by using the regional context. Although the process of the economic globalization extends the international cooperation and exchange all over the world, or interconnects the particular subjects from wherever in the world, regionalism is not in conflict with the globalization trends. On the contrary. To a great extent, it is a reaction to the liberalization trends, especially, it is a defensive reaction which does not necessarily have to adopt the form of protectionism. Rather, it is the utilization of the regional potential, including the revival and transformation of the traditional structures so as to make them satisfactory in view of the present demands of the international labour division. Consequently, there is the rebirth of regions (Hettne-Sönderbaum: 2002, pp. 33-47), when the natural regional labour division is developed at the microeconomic scale, often within its macroeconomic frame. Paradoxically, the rebirth of regions, which strengthens regional solidarity, is a manifestation of the new regionalism, which, on one hand, develops natural structures, and, on the other hand, develops non-traditional cooperation thanks to the institutional standardization.

The interpretation of the rebirth of regions ,results from a meticulous regional analysis and from the defining of five region levels, including the conception of so called

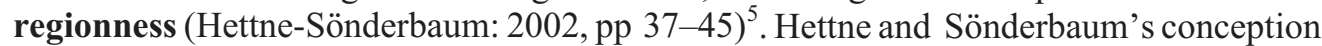
of regionness as a regional identity, as an approach of being in concordance with the outside world, not as an artificial conception, but, on the contrary, as a natural manifestation of regional existence, as a feeling of belonging to a particular region, and therefore as regional cooperation developing objectively.

„Regionness is conceived as an internal, immanent ability to create regions, as a regional delimitation against other regions, defining of proper characteristics, and therefore being able to use maximally its own potential and affect the regional policy for its own benefit,“ (Kučerová: 2006, p. 82) which can be expressed, among others, by the term of regional resistance. ,... it is an entity beyond dispute that can be characterized as a relatively coherent territorial subsystem (in contrast to the non-territorial subsystem) as opposed to the rest of the global system." (Hettne-Sönderbaum: 2002, p. 37). The degree of regionness corresponds to the extent of regional solidarity, as it refers to an unlimited number of subjects that aim together to create regional relations, and, to a certain extent, that become dependent on each other. The conception of the regional resistance corresponds to the strategic intentions of the regional partners, that is, to secure the immunity of resource, competition and security. The conception of the regional resistance, or security, is logically in accordance with the protection of public interests.

A supportive mechanism of regionalism is regionalization, especially by means of the economic integration of various forms and depth. Regionalization is a traditional approach

5 A chapter dealing with regionness has a significant name: Theorising regionness. 
to the international labour division, but its manifestations in the course of the 90's differed from one another completely, especially by the extent of the integration agreements concluded at that time, or by the renegotiation of contracts that had already been in vigour for several decades. ${ }^{6}$

Apart from that, there are changes in the depth of integration, as some coalitions concluded on the creation of customs union or on a common market, instead of creating free trade zones that had been the most wide-spread. In addition, the member bases of the integrating countries are expanding, actually in all regions. "However, together with the shift of the motives and goals of regionalism under the conditions of globalization, it is also possible to trace certain formal changes... of completely different forms of the regional economic integration.“ (Hnát: 2006, p. 48).

Next to subregionalism, known as generally deeper integration of some states that also participate in other integration activities (a typical example is the Benelux inside the $\mathrm{EU}$, the EU in the Baltic Counsel), there are transregionalism and interregionalism establishing themselves.

A convincing example of transregionalism is the functioning of the APEC, which is a kind of integration associating states from various regions of the world economy. The development in Europe gives evidence of transregionalism least by means of the relations with the ACP Group of States, with some Latin American countries such as Chile or Mexico - see the MEFTA project. Besides, the TAFTA plan for a transatlantic free trade zone between the EU and the U.S. corresponds to transregionalism.

Another progressive change in the international relations is the appearance of interregionalism, consisting in the integration activities between two independent integration organizations, i.e. bilateral negotiation. In the past, the particular associations negotiated with each state separately, but, in the last years of the $20^{\text {th }}$ century, there was a significant change, as the negotiators became the representatives of the particular associations. An example is the negotiation between the EU and Mercosur, the ASEM Platform - that is the Asia-Europe cooperation between the UE and the ASEAN, the association agreement between the EU and the Gulf Cooperation Council (GCC).

It is apparent from the lines above that the world is being interconnected more and more, and not only because of the traditional international trade and the trade with intellectual property, but especially because of the transactions of capital, and information channels. From this point of view, the traditional organization structures are confronted with intervention from outside. Therefore, the protection of the public interests, and the obligations of the public sector towards the economic subjects have to undergo transformation, so as to keep up with the globalization challenges. A possible approach is regionalism in conceived as the strengthening of regional resistance in an open economy.

\section{Conclusion}

The economic globalization makes qualitative changes in the conditions of the international relations by a higher openness of the economies, by institutional standardization and by changing the role of the state in economy. The business, capital and information interconnection of the world strengthens the competitive pressure, which the states try to challenge by the increase of regional cooperation.

6 This is especially the case of Latin American of African associations that were established during the 60's and the 70 's, and now they have failed to keep up with the conditions of the globalized world economy. 
There are various motivations for outsourcing. Above all, we can point out the pressure on the increasing of effectiveness, the tax optimization of the companies, a closer approach to the consumer market, the environmental aspects, and the expansion to foreign markets.

On one hand, regionalism strengthens the regional relations; on the other hand, it uses the possibility of cooperating with distant regions. Regionalism is a purposeful approach of the states in the globalization era - a new regionalism, aiming to maximize the positives of multilateralism. The regional dimension remains an important aspect, but not always only as a geographical term. Therefore, transregionalism and interregionalism are developing in reaction to the challenges of globalization.

\title{
Bibliography
}

ARON, R. 1968. Main Currents of Sociological Thought. Doubleday, NY

Brittan,S. In Financial Times, 1996/07/06.

CZIKZENTMIHALY, M. 2005. www.thtconsultung.com

FÁREK, J. 2005. Výzvy globalizace, euroregionálni príhranični spolupráce a zahranični investování.

HAMPDEN-TURNER, Ch. 2005: www.thtconsultung.com

HETTNE, B.; SÖNDERBAUM, F. 2002. Theorising the rise of regionnes. In New Regionalisms in the Global Political Ekonomy. London : Routledge, 2002.

HNÁT, P. 2005. Evropský transregionalismus v kontextu světového vývoje. In Nový regionalismus ve světě a v Evropě, VŠE Praha : Nakladatelství Oeconomica, 2005.

KIROVOVÁ, I. 2006. Global and Local Organisations Requirements. In Globalizace versus Regionalismus. Sborník mezinárodní konference HF TU Liberec, duben 2006.

KOTTAK, C. Ph. 1996. Mirror for Humanity. 1996.

KUČEROVÁ, I. 2006. Nový regionalismus versus geografický regionalismus. VZ FSV UK listopad 2005. In sbornik matfyzpress, Praha, 2006, pp. 67-89.

McLUHAN, M. H,1968. Wear and Peace. In the Global Village.

McLUHAN, M. H. 1989. One Global Village.

OI, C. J. 2005. Corporate Restructuring and Social Security in China's State Owned Enterprises. In Managing Globalisation, NU of Singapore, 2005.

SAMUELSON, P. A. 2005: Global Viewpoint, 2005.

STEIMETZOVÁ, D. 2005: Regionalismus a globalizace. In Nový regionalismus ve světě a Evropě, VŠE Praha, 2005.

STIEGLITZ, J. 2001. Project Syndicate.

SUŠA, O. 2004. Rozvoj české společnosti v EU. Matfyzpress. Praha : FSV UK, 2004.

\section{A Response to Gradual Globalization: Regionalism}

\begin{abstract}
The process of the economic globalization limiting the autonomy of national subjects completed the disintegration of the Westphalian system. The rebirth of regionalism, as another phase of the world economy regionalization, is a logical defensive reaction. However, apart from the regional labour division, a new regionalism emerges, interconnecting even distant subjects. Next to the usual economic reasons, the new regionalism is motivated also by the strengthening of regional resistance. It is the strategy that plays a major role in the development of regionalism.
\end{abstract}

Key words: regionalism; globalization; public sector; the concept of regional resistance the rebirth of regions. JEL classification: F02, F5, F59, L14, O8, R11. 